\title{
METASTATIC RENAL CELL CARCINOMA IN ENDOMETRIAL CAVITY: A RARE CASE REPORT
}

Sarita Nibhoria ${ }^{1}$, Kanwardeep Kaur Tiwana², Tanvi Monga ${ }^{3}$

\section{HOW TO CITE THIS ARTICLE:}

Sarita Nibhoria, Kanwardeep Kaur Tiwana, Tanvi Monga. "Metastatic Renal Cell Carcinoma in Endometrial Cavity: A Rare Case Report". Journal of Evolution of Medical and Dental Sciences 2014; Vol. 3, Issue 15, April 14; Page: 3932-3934, DOI: $10.14260 /$ jemds/2014/2378

\begin{abstract}
Renal cell carcinoma (RCC) has unpredictable and diverse behaviour. The classic triad of hematuria, loin pain and abdominal mass is uncommon at time of presentation. About $30 \%-50 \%$ of patients are found to have metastases at the time of diagnosis. Bones, lungs, liver and brain are the frequent sites of metastases. RCC with metastasis to the endometrial cavity is rarest manifestation, as seen in our patient. Patient was a 40 year old female, G3P1, known case of renal cell carcinoma, presenting in emergency with bleeding per vaginum. She had no other co-morbidity. Endometrial curettage was done and specimen sent for histopathological examination, which revealed metastasis from clear cell type of renal cell carcinoma in endometrial cavity and was confirmed on IHC.
\end{abstract}

KEYWORDS: Endometrial cavity, Metastasis, Renal cell carcinoma

INTRODUCTION: Renal cell carcinoma (RCC) has unpredictable and diverse behaviour. The incidence of RCC over last 20 years has progressively increased due to widespread use of modern imaging. ${ }^{1}$ About $30 \%-50 \%$ of patients are found to have metastases at diagnosis. While bone, lymph nodes, lungs and brain constitute expected 'homing' sites, metastasis may turn up at the unusual locations (skin, testis, maxillary antrum and tongue). ${ }^{2-4}$ Uterus is a rare site of metastasis, because of dense stroma and less vascularity.

Metastatic RCC to endometrial cavity of uterus is extremely rare and usually associated with left sided RCC; only four case reports have been published so far, that too in cervix uteri.5-8 There is one report in the literature of metastatic oncocytic papillary RCC to the endometrium in an 89-yearold woman, who presented with vaginal bleeding. ${ }^{9}$ The exact mechanism is not known; however retrograde venous flow of tumor cells from left renal vein to the left ovarian vein and cervical and vaginal venous plexus explains the spread of left sided RCC to uterus.

CASE REPORT: A 40 year female, G3P1, presented in emergency with complaint of vaginal bleeding since 1 day. She was known case of renal cell carcinoma and had history of inability to conceive past 17 years. On examination the patient was conscious, oriented, her vital parameters were normal, no lymph nodes were palpable. On general and systemic examination, no abnormality was detected. Investigations in form of CT scan were done highlighting growth in endometrial cavity (Figure1) Dilatation and curettage was done and endometrial and cervical curettings were sent for histopathological examination.

Endometrial biopsy received in the form of multiple grey white soft pieces together measuring $0.8 \mathrm{~cm} \times 0.5 \mathrm{~cm} \times 0.3 \mathrm{~cm}$. Microscopically, sections examined from endometrial curretings revealed presence of tumour arranged in sheets. The individual tumour cells were round to oval, having central nucleus with prominent nuclei in some and clear cytoplasm. Also included in the biopsy was endocervical tissue which was free from tumour. (Figure $2 \& 3$ ). 
DISCUSSION: RCC represents a potentially lethal cancer that is associated with aggressive behaviour and has a propensity for metastatic spread. The patterns of metastases from RCCs are not yet defined with accuracy and, as a result, RCC has been associated with rare metastatic sites and occasionally atypical presenting symptoms from disseminated disease and distant metastatic sites. Relatively few case reports of primary extra-pelvic carcinomas with metastasis to uterus have been published. The most frequent primary carcinomas metastasizing to uterus and cervix are the breast, stomach, ovarian and colorectal cancers. ${ }^{10}$

Renal Cell carcinoma (RCC) may remain clinically occult for the most of its course and the tumour in the kidney may progress unnoticed to a large mass until metastases appear. About two third of cases of RCC metastasize to lungs, liver and bones. Only less than $0.5 \%$ cases metastasize to female genital system. ${ }^{11}$

The present review has focused on rare incidence of metastatic spread of RCC to endometrial cavity of uterus, which is an extremely rare site for metastasis. This fact further highlights the significance of case reporting, especially in oncology where clinical trials or even large case series are not always available; as Dib et al. have very elegantly pointed out. ${ }^{12}$ The contribution of case reporting should not be underestimated since many of our classical clinical teachings have originated from the observation of isolated "case reports".

\section{REFERENCES:}

1. Tunio MA, Hashmi A, Rafi M. Need for a new trial to evaluate postoperative radiotherapy in renal cell carcinoma: A meta-analysis of randomized controlled trials. Ann Oncol 2010; 21: 1839-1845.

2. Tunio MA, Hashmi A, Rafi M. Epistaxis and proptosis -Unusual primary manifestations of metastatic renal cell carcinoma. Pak J Med Sci 2009; 25: 1012-1014.

3. Tunio MA, Hashmi A, Rafi M. Renal cell carcinoma with initial presentation as erythematous skin metastasis. Isra Medical Journal 2009; 1: 79-81.

4. Tunio MA, AlAsiri M, Ahmad S, Fareed M, Bayoumi Y. Tongue metastasis as an initial manifestation of metastasis in renal cell carcinoma: A case report. J Solid Tumors 2012; 2: 39-42.

5. Seseke F, Kugler A, Hemmerlein B, Gross AJ, Ringert RH, et al. Metastasis from renal cell carcinoma to the cervix uteri. Scand J Urol Nephrol 1998; 32: 290-292.

6. Bozaci EA, Atabekoğlu C, Sertçelik A, Unlü C, Ortaç F. Metachronous metastases from renal cell carcinoma to uterine cervix and vagina: case report and review of literature. Gynecol Oncol 2005; 99: 232-235.

7. Zafrakas M, Papanikolaou AN, Venizelos ID, Kellartzis D, Agorastos T, et al. A rare case of renal cell carcinoma metastasizing to the uterine cervix. Eur J Gynaecol Oncol 2009; 30: 239-40.

8. Godfrey GJ, Moore G, Alatassi H. Presentation of renal cell carcinoma as cervical polyp metastasis. J Low Genit Tract Dis 2010;14: 387-389.

9. Koike H, Okamoto T, Tanji S, Fujioka T, Kubo T, Ohhori T. Two cases of metastatic renal tumor. Hinyokika Kiyo 1989, 35(3):475-479.

10. Pérez-Montiel D, Serrano-Olvera A, Salazar LC, Cetina-Pérez L, Candelaria M et al. Adenocarcinoma metastatic to uterine cervix: a case series. J Obstet Gynaecol Res 2012;38: 541549.

11. Modi PR, John PJ, Joshi DP, Rohit NJ. Vaginal metastasis from renal cell carcinoma - a case report. Indian J Urol 2004;20: 169-170. 


\section{CASE REPORT}

12. Dib EG, Kidd MR, Saltman DC: Case reports and the fight against cancer. J Med Case Reports 2008, 2:39.

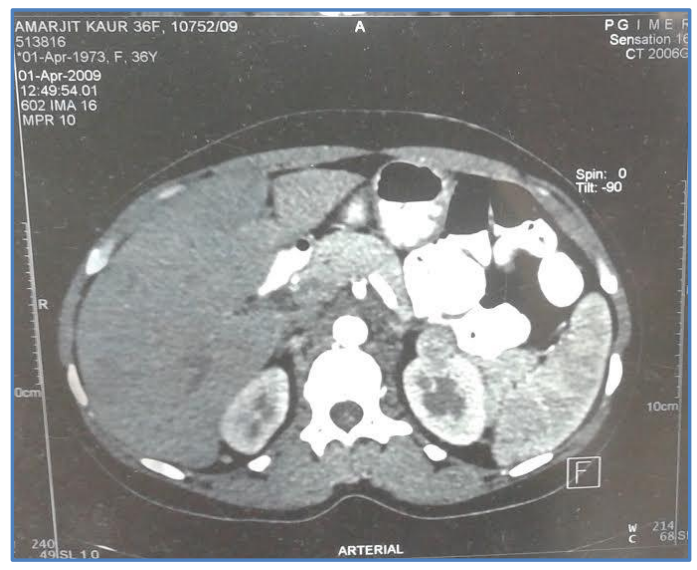

Figure 1: CT Scan

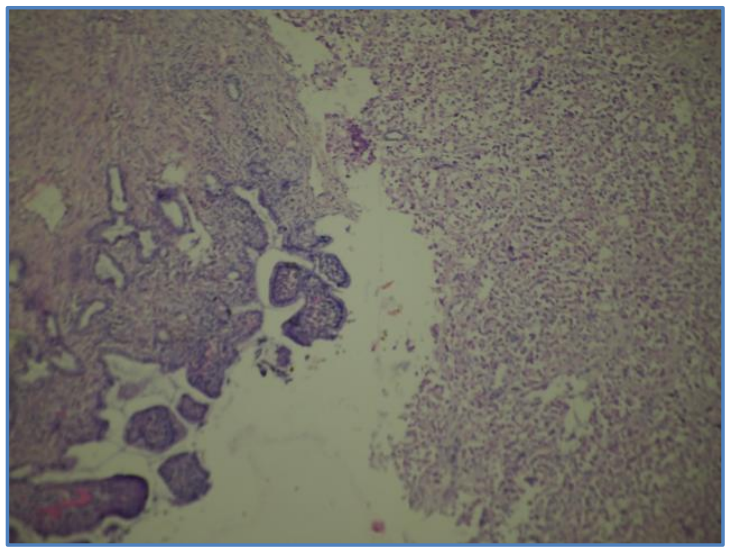

Figure 2

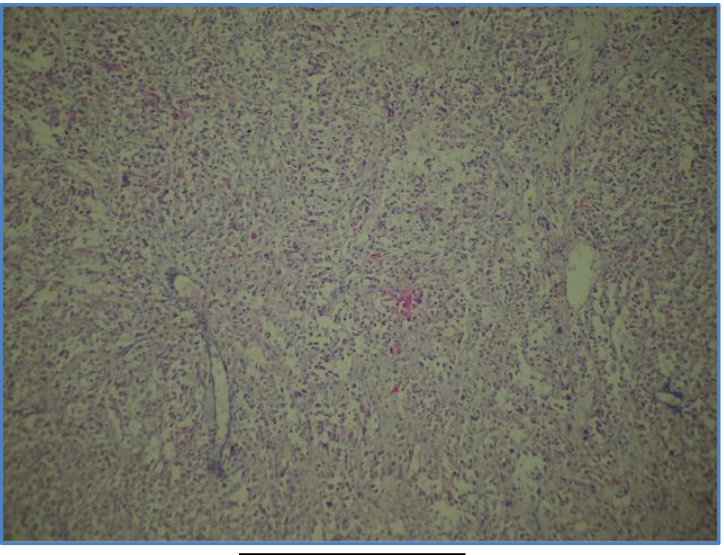

Figure 3

\section{AUTHORS:}

1. Sarita Nibhoria

2. Kanwardeep Kaur Tiwana

3. Tanvi Monga

\section{PARTICULARS OF CONTRIBUTORS:}

1. Associate Professor, Department of Pathology, Guru Gobind Singh Medical College, Faridkot.

2. Associate Professor, Department of Pathology, Guru Gobind Singh Medical College, Faridkot.

3. Junior Resident, Department of Pathology, Guru Gobind Singh Medical College, Faridkot

\section{NAME ADDRESS EMAIL ID OF THE CORRESPONDING AUTHOR:}

Dr. Kanwardeep Kaur Tiwana, H. No. 75, Medical College Campus, Sadiq Road, Guru Gobind Singh Medial College, Faridkot - 151203, Punjab.

E-mail: kanwardeepjhajj@gmail.com

Date of Submission: 16/03/2014. Date of Peer Review: 17/03/2014. Date of Acceptance: 27/03/2014. Date of Publishing: 09/04/2014. 